Kwartalnik Historyczny

Vol. CXXVIII, 2021

Eng.-Language Edition no. 5, pp. 105-129

PL ISSN 0023-5903

MAREK SZAJDA

https://orcid.org/0000-0002-1938-6762

Institute of History, University of Wrocław

\title{
'OUT OF POLAND, NOT TO ISRAEL, BUT OUT OF POLAND': FACTORS INFLUENCING THE DECISION TO LEAVE POLAND AFTER MARCH 1968: ON THE BASIS OF RESEARCH FROM THE 1970s
}

Abstract: In this article the author explores the question of Jews' emigration from Poland to Israel after the events of the anti-Zionist campaign of 1968. On the basis of émigrés' accounts recorded in the 1970s, the author has reconstructed the complex mosaic of factors influencing their decision to leave Poland and choose Israel as their final destination. The most important among these factors were: the 'anti-Zionist campaign' and anti-Semitism of the period, as well as the resulting sense of alienation and stigmatization; the large number of people leaving the country, in particular those with family ties and relationships; disappointment with communism; and the Warsaw Pact's invasion of Czechoslovakia.

Ke yw ords: 1968 anti-Semitic campaign, emigration, Jewish population, March 1968, Israel, communism.

The question of post-March emigration ${ }^{1}$ is one of the many components of the subject of the 'anti-Zionist campaign' of $1967-68,{ }^{2}$ or the events of March 1968 in Poland. ${ }^{3}$ Although it has been described a number

${ }^{1}$ The phrase 'post-March emigrtion' or 'post-March émigrés' refers to Jews and people of Jewish origin who left Poland following the events of March 1968 and the anti-Semitic campaign.

${ }^{2}$ Dariusz Stola, Kampania antysyjonistyczna w Polsce 1967-1968, Warsaw, 2000.

${ }^{3}$ Among the most important studies, see Jerzy Eisler, Marzec 1968: Geneza, przebieg, konsekwencje, Warsaw, 1991; idem, Polski rok 1968, Warsaw, 2006; Marzec 1968: Trzydzieści lat później: Materiały z konferencji zorganizowanej pod patronatem prezydenta $m$. stoł. Warszawy przez Instytut Historyczny UW, Instytut Studiów Politycznych PAN oraz Żydowski Instytut Historyczny przy wspótpracy Wydawnictwa Naukowego PWN SA na Uniwersytecie Warszawskim 6 i 7 marca 1998 r., 2 vols, Warsaw, 1998, vol. 1: Referaty, ed. Marcin Kula, Marcin Zaremba and Piotr Osęka; Piotr Osęka, Syjoniści, inspiratorzy, wichrzyciele: Obraz wroga w propagandzie marca 1968, Warsaw, 1999; idem, Marzec '68, Cracow, 2008. 
times, ${ }^{4}$ it continues to be a fascinating research topic, attracting the interest of scholars dealing with modern history as well as with problems of identification, identity ${ }^{5}$ or migration. ${ }^{6}$ As Dariusz Stola has observed, these issues were among the most visible effects of the entire campaign, and at the same time one of the first issues raised by the government. The post-March emigration involved around 13,000 Jews and people of Jewish origin ${ }^{8}$ who, as a result of various events and experiences were caught up in an anti-Semitic campaign and left Poland in 1968-71. They moved to various countries; mainly Denmark, Sweden, Israel, and the United States. ${ }^{9}$ It was precisely their choice of destination that determined their subsequent creation of a new identity, integration with the local society, as well as the émigrés' attitudes toward Poland. The lives of the March émigrés in Scandinavia, North America, or Israel to some extent were (and still are) different experiences. ${ }^{10}$ In addition to such different countries and thus different societies, what also matters in this regard is the context of earlier experiences of the individuals leaving Poland: their cultural background and, above all, their age and perception of reality through earlier experiences. It is worth stressing at the

${ }^{4}$ Dariusz Stola, Emigracja pomarcowa, Warsaw, 2000; idem, 'Anti-Zionism as a Multipurpose Policy Instrument: The Anti-Zionist Campaign in Poland, 1967-1968', Journal of Israeli History, 25, 2006, 1, pp. 175-201; idem, Kraj bez wyjścia? Migracje z Polski 1949-1989, Warsaw, 2010; idem, 'Jewish Emigration from Communist Poland: The Decline of Polish Jewry in the Aftermath of the Holocaust', East European Jewish Affairs, 47, 2017, 2-3, pp. 169-88.

${ }^{5}$ Marcin Starnawski, Socjalizacja i tożsamość żydowska w Polsce powojennej: Narracje emigrantów z pokolenia marca '68, Wrocław, 2016.

${ }^{6}$ Łukasz Górniok, Swedish Refugee Policymaking in Transition?: Czechoslovaks and Polish Jews in Sweden, 1968-1972, Umeå, 2016. The post-March emigration is an important element of the subject of Jewish emigrations from Poland after the Second World War, see Bożena Szaynok, 'Raport o stanie badań na temat emigracji z Polski Żydów obywateli polskich po II wojnie światowej (1944-1989)', in Polska emigracja polityczna 1939-1990: Stan badań, ed. Sławomir Łukasiewicz, Warsaw, 2016, pp. 395-425.

7 Stola, Kampania antysyjonistyczna, pp. 207-08. Dariusz Stola is also the author of the phrase 'post-March emigration'.

8 Grzegorz Berendt, 'Emigracja ludności żydowskiej z Polski w latach 1945-1967', Polska 1944/45-1989: Studia i Materiały, 7, 2006, pp. 25-60 (p. 60).

${ }^{9}$ Stola, Kraj bez wyjścia?, p. 221.

${ }^{10}$ These differences are examined by for example Kamila Dąbrowska, see University of Warsaw Archives, No. Whdr11 1351, Kamila Dąbrowska, 'Od autobiografii do historii konstruowanie pamięci indywidualnej i zbiorowej Żydów mieszkających na Dolnym Śląsku po II wojnie światowej', doctoral dissertation, Faculty of History, University of Warsaw, 2011, pp. 93-178 (Chapter 'Diasporowe społeczności w nowych krajach zamieszkania'). The topic has also been raised by another scholar, who writes about the problems of assimilation in Scandinavia; see Marcin Starnawski, 'Pokolenie Marca '68 na wygnaniu: Wzory integracji i zmiany identyfikacyjne', Kwartalnik Historii Żydów, 2019, 2, pp.389-416. 
same time that thanks to regular reunions taking place in Israel since 1989, émigrés from different countries have remained in touch. For more than a decade these contacts have been developed through online fora or during regional reunions. ${ }^{11}$

So far the largest number of accounts presenting the 'March' experiences have been published via interviews with the generation of the children of Holocaust survivors, born mostly shortly after the end of the Second World War. The best example of this is the book by Joanna Wiszniewicz featuring narratives of the post-1968 émigrés - teenagers and young adults - in a biographical perspective. ${ }^{12}$ The number of similar works, including not only books but also oral history projects, is growing every year..$^{13}$ Today it is the generation of seventy- and eighty-year-olds who are the most important voices - witnesses to the events from over a half a century ago. ${ }^{14}$ It is also worth referring in this context to Julian Ilicki's earlier pioneering studies concerning people arriving in Scandinavia ${ }^{15}$ or a survey carried out and published by the Paris Kultura in $1970 .^{16}$

The present paper focuses on the experiences of individuals leaving Poland for Israel, but from the perspective of adults born long before the outbreak of the Second World War, that is representatives of the Holocaust generation and parents of the youth of March 1968. ${ }^{17}$ In order to reconstruct their life stories and decisions made over fifty years ago I use a unique source: archive material in the form of twenty accounts from the 1970s collected in Israel by another émigré of the

${ }^{11}$ See the website 〈http://www.reunion68.se/ > [accessed 29 October 2020]. Also Leopold Sobel, "Budujemy nowy dom": Polska i emigracja marcowa w materiałach opublikowanych w "Plotkies"', in Społeczność żydowska w PRL przed kampania antysemicka lat 1967-1968 i po niej, ed. Grzegorz Berendt, Warsaw, 2009, pp. 218-27.

${ }^{12}$ Joanna Wiszniewicz, Życie przecięte: Opowieści pokolenia Marca, Wołowiec, 2008.

${ }^{13}$ Among the more important publications of interviews with émigrés, see for example Krajobraz po szoku, ed. Anna Mieszczanek, Warsaw, 1989; Krystyna Naszkowska, Ani tu ani tam: Marzec '68 - powroty, Warsaw, 2018; Krystyna Naszkowska and Joanna Helander, Wygnani do raju: Szwedzki azyl, Warsaw, 2017; Teresa Torańska, Jesteśmy: Rozstania '68, Warsaw, 2008.

${ }^{14}$ Two of the most recent publications of interviews with post-March émigrés, see Mikołaj Grynberg, Księga wyjścia, Wołowiec, 2018; Agata Tuszyńska et al., Bagaż osobisty: Po Marcu, Warsaw, 2018.

${ }^{15}$ Julian Ilicki, Den föränderliga identiteten: Om identitetsförändringar hos den yngre generationen polska judar som invandrade till Sverige under åren 1968-1972 [The Changeable Identity: On Changing Identity among the Younger Generation of Polish Jews Immigrating to Sweden in 1968-1972], Åbo, 1988.

${ }^{16}$ Kamila Chylińska, 'Emigracja polska po 1967 r.', Kultura, 1970, 11/278, pp. 17-55.

${ }^{17}$ Piotr Osęka, My, ludzie z Marca: Autoportret pokolenia '68, Warsaw and Wołowiec, 2015. 
post-March Aliyah, ${ }^{18}$ the scholar Sabina Lewin. Her interviewees were almost all fifty and sixty years old at the time, with the exception of two around twenty.

In analysing the interviews conducted by Lewin, I discuss only one selected aspect: the decision to leave Poland. The main research question in the present article is: What determined such a decision and which factors had the largest impact on the decision of the emigration among the Jews in Poland?. In this regard I draw on earlier findings, including those of Dariusz Stola, to examine to what extent the accounts in question reveal other contexts of emigration from Poland after the March 1968.

\section{Sources and Study Group}

When describing the archive material in question, it is difficult to determine whether these documents originated as a result of, for example, oral history interviews. ${ }^{19}$ There are no notes made during the interviews nor detailed records of each interview, and most importantly there is little if any information about whether an interview was recorded or evidence of any recording being made. Nor are the analysed accounts traditional transcripts, and even if they are they certainly underwent a detailed editing process with regard to the language. Although the interviews concern the entire life of the interviewees, the method used in them is not that of a sociological autobiographical interview. ${ }^{20}$ There are no clearly defined interview stages and, most importantly, no free-flowing life stories. Most of the accounts are in the form of fairly short answers to questions, not always presented in the first person. I have not been able to establish whether the interviews were authorized for publication or whether they were used and published by the authors themselves. ${ }^{21}$ On the basis of these elements it is not possible to say whether the analysed accounts are qualitative, similar to sociological in-depth interviews, or simply surveys with answers provided by individuals asked to do so. In order to place the respondents' an-

${ }^{18}$ Aliyah - a Hebrew term referring to the migration of Jews to Palestine and then to Israel.

${ }^{19}$ Understood as a recorded conversation between a scholar and a witness to history about the past - the interviewee's life experiences. See Marta Kurkowska-Budzan, 'Informator, świadek historii, narrator - kilka wątków epistemologicznych i etycznych oral history', Wrocławski Rocznik Historii Mówionej, 1, 2011, pp. 9-34.

${ }^{20}$ Kaja Kaźmierska and Katarzyna Waniek, Autobiograficzny wywiad narracyjny: Metoda - technika - analiza, Łódź, 2020.

${ }^{21}$ One account became the basis of a source study: Marek Szajda, "Epilog "Historii złudzeń": Obraz Polski w latach 1944-1968 we wspomnieniach Klemensa Nussbauma', Sobótka, 74, 2019, 3, pp. 137-63. 
swers in a broader context, I have attached an annex featuring the questionnaire with the questions formulated by Lewin.

As a separate issue, I would like to place the material in question in the context of the interviewees' life experiences. Their accounts were collected barely a few years after their arrival in Israel, in 1976-77. Thus they share their experiences from a relatively short time-perspective of just a few years, and so their memories are linked to the present, that is as it was at the time and to what they experienced after their migration. Among the most important events I would single out the atmosphere after the victory in the Six-Day War, as well as the 1973 conflict known as the Yom Kippur War. At the same time those few years were a time of the first experiences of adaptation to a new culture or language. The interviewees must have already become - partly, even if to a limited degree - acculturated or assimilated in Israeli society. ${ }^{22}$ All this may have influenced their answers and stories of emigration. ${ }^{23}$

The analysed group of respondents is characterized by a high coherence of life experiences. Before I discuss in detail the specificity of the twenty accounts cited herein, ${ }^{24}$ it is worth presenting the respondents themselves. One of the most important observations concerns the interviewees' age. ${ }^{25}$ On the basis of the information provided by them, they can be described as representatives of one generation, understood in terms of a shared language and experience: people born during the First World War or within a few years after its end. ${ }^{26}$ Thus they are people who grew up and lived their youth - and thus went through the process of socialization in the Second Polish Republic. On the eve of the Holocaust they were

${ }^{22}$ For more on the problems associated with the group's assimilation in Israel, see Elżbieta Kossewska, Ona jeszcze mówi po polsku, ale śmieje się po hebrajsku: partyjna prasa polskojęzyczna a integracja kulturowa polskich Żydów w Izraelu (1948-1970), Warsaw, 2015, pp. 84-89, 253-80.

${ }^{23}$ Agata Stolarz, 'Dzielenie się pamięcią': Praktyka i teoria historii mówionej, Lublin, 2016, pp. 158-60.

${ }^{24}$ Archive of the Diaspora, Tel Aviv (hereinafter AD), fonds A-7, 'Interviews with emigrants from Poland from the 1969-1970 Aliyah', no. 1-20.

${ }^{25}$ When replying to questions concerning their age, most of them gave a specific number or year of birth. Six individuals described themselves as middle-aged. This is a fairly broad category, which encompasses both forty-year-olds and those who are ten or twenty years older. This general phrase can be made more precise by the averaging of the numbers given by other respondents. The median for the other cases, with specific numerical values, is sixty years, while the median without the two lowest values - assuming that the two individuals aged twenty-seven and twenty-nine represented another generation (children and not the parents) - is sixty-one years. The calculations for the averages are slightly different though similar: fifty-five and sixty years respectively.

${ }^{26}$ See the entry 'Pokolenie' (Generation), in Słownik socjologii i nauk społecznych, ed. Gordon Marshall and Marek Tabin, Warsaw, 2004, p. 240. 
twenty-somethings, which undoubtedly influenced their decisions and strategies, or rather their possibilities of surviving the Second World War. The post-war period, which they spent in Poland until their departure, was a time of intensified work and life in reconstructed or new families. The respondents lived in Poland's major cities, which had large Jewish communities - cities like Warsaw, Łódź, and Wrocław. ${ }^{27}$

What must be regarded as extremely important are the respondents' wartime experiences. Most survived the period in the Soviet Union (fourteen respondents). However, their routes back to Poland after the war were different. Some returned as part of the 'repatriation' campaign in 1946 (seven respondents), others with the military, having enlisted in the 1st Division or the later 1st Army (four respondents). There were also those who waited for the moment until the second half of the 1950s and the 'second repatriation' (three respondents). ${ }^{28}$ Only four individuals survived the Holocaust in Poland, all of them on the Aryan side. Towards the end of the war two of them were transported deep into the Third Reich as forced labourers.

The Holocaust changed many aspects of the life of the Jewish community in Poland, beginning with the obvious facts concerning the size of the total population, location of the various communities, and employment structure. Equal rights - as declared in the new political situation $^{29}$ - as well as the 'productivization' of the Jews ${ }^{30}$ changed the population's vocational structure. The sphere to which the respondents were granted the broad access in the post-war period was education. A vast

${ }^{27}$ In the first few years after the end of the Second World War these cities had relatively the largest Jewish populations, see Andrzej Rykała, Przemiany sytuacji społeczno-politycznej mniejszości żydowskiej w Polsce po drugiej wojnie światowej, Łódź, 2007, pp.37-47.

${ }^{28}$ For more see Małgorzata Ruchniewicz, Repatriacja ludności polskiej z ZSRR w latach 1955-59, Warsaw, 2000.

${ }^{29}$ This phenomenon can be summed up after August Grabski as follows: 'in this situation [of equal rights - M.S.] it is not surprising that they [the communists M.S.] were supported by the Jewish community in Poland (and part of the international Jewish community), and that Polish Jews who had survived the Holocaust and decided to stay in Poland took up various offers of collaboration, promotion and equal rights presented to them by the communists,' cf. August Grabski, 'Żydzi a polskie życie polityczne (1944-1949)', in Następstwa zagłady Żydów: Polska 1944-2010, ed. Feliks Tych and Monika Adamczyk-Garbowska, Lublin, 2011, pp. 157-88 (pp. 187-88).

${ }^{30}$ I understand 'productivization' as not only a transformation of the employment structure of the Jewish population, but also the inclusion of this group in the objectives of the planned economy developed at the time, that is a combination of the situation of Jews after the Holocaust and policies pursued by the communists. See Andrzej Rykała, “"Produktywizacja” Żydów w Polsce po drugiej wojnie światowej na przykładzie działalności rolniczej’, Prace i Studia Geograficzne, 61, 2016, 1, pp. 151-63. 
majority of them (eighteen) completed their education at the time, receiving high school or university diplomas. No fewer than sixteen respondents boasted of the latter, which is further evidence, as it were, of the intellectual lineage of the post-March émigrés. ${ }^{31}$ It is worth noting that in some cases the universities and diplomas were linked to the respondents' involvement in the political system - several of them graduated from the so-called 'Party schools'.

Finally, we need to examine the interviewees' political activity. Most of them were involved in the work of various organizations in the inter-war period. These included mainly the Communist Party of Poland (KPP), the Communist Party of Western Ukraine, International Red Aid as well as others, like Hashomer Hatzair. ${ }^{32}$ Importantly, the respondents frequently noted their time spent in prisons, a consequence of their involvement in illegal activities. In some cases the imprisonment lasted as long as a few years. There is an evident radicalism of attitudes in these descriptions, as well as a deep interest in communism. The ideology must have constituted a concrete proposal in response to the rising anti-Semitism or the experience of Polish-Jewish relations in the Second Polish Republic. ${ }^{33}$ Communism was attractive also thanks to its utopian message, promise of no class divisions, ${ }^{34}$ and the alleged power of and order in the Soviet Union. ${ }^{35}$

For some, who had been in the USSR during the war, it was natural to be active in the Union of Polish Patriots, ${ }^{36}$ and after their return to Poland also in the Polish Workers' Party and then in the Polish United Workers' Party (PZPR). In the latter case however, the respondents do make a distinction between active, non-active, ordinary, and passive members, or members performing specific functions, for example in the Basic Party Organization in their work places. All this information

${ }^{31}$ Stola, Emigracja pomarcowa, p. 10.

${ }^{32}$ Hashomer Hatzair, Hebrew for 'Young Guard', a left-wing-Zionist youth organization based on the scouting method.

${ }^{33}$ Kamil Kijek, Dzieci modernizmu: Świadomość, kultura i socjalizacja polityczna młodzieży żydowskiej w II Rzeczypospolitej, Wrocław, 2017, pp. 390-92.

${ }^{34}$ Antony Polonsky, Dzieje Żydów w Polsce i Rosji, Warsaw, 2014, p. 336.

${ }^{35}$ Kijek, Dzieci modernizmu, pp. 393-94. For more see Marci Shore, Caviar and Ashes: A Warsaw Generation's Life and Death in Marxism, 1918-1968, New Heaven, CT, and London, 2006.

${ }^{36}$ As Mirosław Szumiło has rightly noted, the large percentage of Jews among high-level activists of the Union of Polish Patriots was the result of not just a large number of Jews in the USSR, but also a considerable number of Jewish communists, who were trusted and well-educated. Cf. Mirosław Szumiło, 'Żydzi w kadrze kierowniczej Związku Patriotów Polskich w ZSRS (1943-1946)', in Elity i przedstawiciele społeczności żydowskiej podczas II wojny światowej, ed. Aleksandra Namysło and Martyna Grądzka-Rejak, Cracow, Katowice and Warsaw, 2017, pp. 337-50. 
seems to be especially important in the context of the reasons behind their leaving Poland, which are discussed below.

The group portrait of Sabina Lewin's interviewees corresponds to Jaff Schatz's study ${ }^{37}$ devoted to the generation of Jewish communists, that is people who long before the outbreak of the Second World War had been formed by the experience of rebellion and turning away from the Jewish tradition. During these years they gained 'formative experience' in political organizations or prisons. They survived the war thanks to their escape to the east, and after returning to Poland they became involved, not always for the same reasons, in the building of the system, or simply Poland, to a greater or lesser extent. Stalinism and the Thaw that followed it prompted many of them to consider emigration, or perhaps simply constituted their first major disappointment. The 'little stabilization' of Władysław Gomułka's rule, and finally the events of March 1968 and the anti-Zionist campaign gave rise to an experience of disappointment and led them to consider emigration. ${ }^{38}$ As Schatz sums it up:

In a way, the wheel had come full circle. Some of the communists of Jewish origin joined the communist youth movement in the 1920s and 1930s, others shortly after the war. Now, leaving, those who understood the magnitude and depth of their defeat said: 'We had dandled a dead baby,. ${ }^{39}$

It should be noted that the group described above does not represent the only - nor an objective - idea of the post-March emigration. It is only part of a broader picture, just as the stories of Joanna Wiszniewicz's interviewees or other accounts are part of a bigger whole. At the same time, this does not change the fact that some people leaving Poland at that time can be identified with these experiences. They are confirmed by, among others, the replies to the Kultura survey, in which half of the respondents admitted to sympathizing with the communist system, adding information about their growing disappointment. ${ }^{40}$

${ }^{37}$ Jaff Schatz, The Generation: The Rise and Fall of the Generation of Jewish Communists of Poland, Lund, 1989; idem, 'Świat mentalności i świadomość komunistów polsko-żydowskich - szkic do portretu', in Społeczność żydowska w PRL przed kampania antysemicka, pp. 43-55.

${ }^{38}$ For more on this process as exemplified by Jewish writers, see Joanna Nalewajko-Kulikov, Obywatel Jidyszlandu: Rzecz o żydowskich komunistach w Polsce, Warsaw, 2009; Magdalena Ruta, Bez Żydów? literatura jidysz w PRL o Zagładzie, Polsce i komunizmie, Cracow and Budapest, 2012, pp. 257-324.

${ }^{39}$ Schatz, 'Świat mentalności', p. 55. Translated from polish.

${ }^{40}$ Chylińska, 'Emigracja polska', p. 23. 
This group probably included Sabina Lewin herself - not only did she meet all the criteria mentioned above, but, above all, she shared the same fate as her interviewees and as a result deeply understood the problems they raised.

\section{Sabina Lewin and Her Experience of Emigration}

Sabina Lewin ${ }^{41}$ was born in 1914 in Ostrowiec nad Kamienną (today Ostrowiec Świętokrzyski) in a Jewish family. Little can be said about her parents; they were probably associated with the Jewish tradition and religion. We know more about her two sisters: Dina, actively involved in the Zionist movement, who made an Aliyah to Palestine in 1932; and Mirosława, an activist in the Communist League of Youth in Poland, then the Communist Party of Poland, who was imprisoned for her communist activism. Between these two extremes, that is two different ideologies and milieus, Lewin found her own path. After finishing high school in 1932, she moved to Warsaw, where she enrolled in the Humanities Faculty of Warsaw University, ${ }^{42}$ at the same time working as a teacher at the school of the Society for the Dissemination of Knowledge in the Jewish Population. Four years later, for reasons that are not entirely clear, she moved to Końskie, where she began working as a teacher at the State School No. 1. This decision meant she had to interrupt her studies. She returned to Warsaw University after 1945.

Germany's attack on Poland in September 1939 had a significant impact on the migration of the Jewish population to the east of the country and, after the attack by the USSR, to the Soviet occupation zone. Like many other Jews, Sabina Lewin attempted to get through to the east. For nearly two years she lived in Sarny (north-eastern Ukraine, currently the Rivne Raion), where she worked in a children's home and a school. After the Third Reich's attack in June 1941, she evacuated deep into the Soviet Union. She found herself in Kirghizia, where she settled in Jalalabad. She began working there in a nursery school and after the founding of the

${ }^{41}$ Biographical note based on documents kept in the personal files in the archives of the University of Warsaw and Tel Aviv University.

${ }^{42}$ It is hard to say what motivation was behind such a choice. It is worth citing studies by Piotr M. Majewski, according to whom the Faculty of the Humanities, University of Warsaw, was one of the faculties with the highest number of Jewish students and was very popular among them. Such choices may have been motivated by a desire to move to other faculties later (for example Faculty of Law, Faculty of Medicine), the open nature of the unit, or career plans and related employment possibilities, cf. Dzieje Uniwersytetu Warszawskiego 1915-1945, ed. Piotr M. Majewski, Warsaw, 2016, pp. 153, 203. 
Union of Polish Patriots, in 1944 she was made the organization's district secretary and head of the education department. In such a position she organized nursery schools and primary schools for the Polish population. After the end of the Second World War she returned to Poland (probably in 1946, under the so-called 'repatriation campaign'), where she continued to work in education as a school inspector at the Ministry of Education in 1948-52.

During that period Sabina Lewin also resumed her studies at the University of Warsaw. In 1954 she obtained an MA in pedagogy at the Faculty of Pedagogy. Soon afterwards she was appointed lecturer and worked in that role until the end of 1959, publishing material for students during that period..$^{43}$ On 6 December 1960 she defended her doctoral thesis, which was published in print in the same year. ${ }^{44}$ In the following years (1962-69) she worked as a senior lecturer in philosophy and pedagogy at the Extramural Teachers' College in Warsaw. During that period she worked on her habilitation and in 1966 she received a scholarship for that purpose from the Council of the Faculty of Pedagogy, University of Warsaw. Her book, devoted to the theoretical foundations of pre-school education in the Polish People's Republic, was published three years later. ${ }^{45}$ Unfortunately, the anti-Semitic campaign and its consequences put an end to her post-doctoral studies. It was during this time that she decided to leave Poland. In September 1969 she handed in her resignation and as early as 10 December she arrived in Israel. In 1971-82 she worked at The Goldstein-Goren Diaspora Research Center, Tel Aviv University. She conducted studies devoted to the Jewish school system in the nineteenth and twentieth centuries. Many of her papers from that period were published in the Gal-Ed journal. Towards the end of her life she published one of her last works in Poland - the publisher was the Jewish Historical Institute. ${ }^{46}$ In the preface to the book she wrote:

This small book is an optimistic examination of my Polish past. My post-doctoral dissertation was published in Warsaw in 1969. Yet before it saw the light of day, the authorities had the entire edition destroyed. This was a punishment for my emigration from Poland. The book was destroyed,

${ }^{43}$ Sabina Lewin, Materiały pomocnicze do historii szkolnictwa i oświaty: dla studentów Studium dla Pracujacych Wydz. Pedagogiki U.W. Cz. 1: Wychowanie w ustroju niewolniczym i feudalnym, Warsaw, 1958.

${ }^{44}$ Eadem, U poczatków polskiej teorii wychowania dziecka $w$ wieku przedszkolnym, Warsaw, 1960.

${ }^{45}$ Eadem, Podstawy wychowania przedszkolnego w Polsce Ludowej, Warsaw, 1969.

${ }^{46}$ Eadem, Żydowska młodzież w strajku szkolnym 1905 r., Warsaw, 1996. 
but the roots have remained. They cannot be destroyed. So this book, currently being published in Poland, is a mark of fulfilment and hope, a reminder of human stories and the healing of painful wounds. ${ }^{47}$

\section{Reasons for Leaving Poland}

Each wave of emigration is characterised by different elements influencing the decision to emigrate. These can be either push or pull factors, as well as individualized or structural factors. ${ }^{48}$ There is no doubt that the emigration of Jews after March 1968 had a political background, and their decisions were influenced by push factors. ${ }^{49}$ They included both the 'anti-Zionist campaign' as well as the government's decision to enable thousands of people to leave by introducing specific departure procedures (including the travel document) - a rare event in communist Poland, in which the international mobility of citizens was strictly controlled by the state. ${ }^{50}$ At the same time each decision to emigrate had its own unique and individual character stemming from the situation of a concrete person or family. According to Everett S. Lee's theory, in addition to push and pull factors, personal factors, and intervening obstacles, another important category is perception..$^{51}$ The individuals' subjective perception of their specific circumstances and reasons leads to an assessment of the situation and, consequently, to making a decision. The significance of this can be discerned in the analysed source material. In the case of the group in question there is no doubt that important elements also included migration networks, family contacts, and the activity of migration institutions. ${ }^{52}$

When analysing the motivations behind leaving Poland, Dariusz Stola mentions several different reasons, including direct persecution, an unbearable atmosphere, and disappointment with real socialism. Just as

${ }^{47}$ Ibid., p. 2. Translated from polish.

${ }^{48}$ Marek Nowak, 'Polska migracja: Motywy mobilności, jej dynamika i propozycja socjologicznej rekonceptualizacji', Ruch Prawniczy, Ekonomiczny i Socjologiczny, 76, 2014, 3, pp. 281-99 (pp. 289-91).

${ }^{49}$ In this context it is possible to use the category of 'redundant' people to refer to all post-March émigrés, which corresponds to emigration for political reasons, see Ewa Jaźwińska, Wojciech Łukowski and Marek Okólski, Przyczyny i konsekwencje emigracji z Polski, Warsaw, 1997, p. 69, Prace Migracyjne, vol. 7.

${ }^{50}$ Jakub Isański, Migracje i transfery kapitału społecznego, Poznań, 2015, p. 51.

51 Paweł Kaczmarczyk, Migracje zarobkowe Polaków $w$ dobie przemian, Warsaw, 2005, p. 29.

${ }^{52}$ See Krzysztof Jaskułowski and Marek Pawlak, 'Główne teorie migracji międzynarodowych: Przegląd, krytyka, perspektywy’, Sprawy Narodowościowe. Seria nowa, 48, 2016, pp. 128-46 (pp. 136-37). 
important are the reasons affecting the Jewish population in particular, including emigration as a process reaching various groups within this community; the examples of acquaintances; the disappearance of the Jewish world, including the decline of Jewish institutions; and last but not least the evolution of identity. ${ }^{53}$ When discussing the interviews, I would like to present those factors that were the most influential when it came to the interviewees' decisions, or at least were regarded as such a few years after their emigration from Poland. Almost all the arguments cited by Stola appear in the interviews and in the émigrés' narratives, although the focus of attention differs for each individual. In identifying and explaining the most frequently-cited reasons, I have distinguished several categories of experiences.

The 'anti-Zionist campaign' - which was in fact an anti-Semitic campaign - encompasses a large number of behaviours and experiences which, taken together, define the phenomenon. Phrases like 'fearing isolation and the wave of anti-Semitism which had been revived, we decided to go to Israel ${ }^{154}$ appear quite frequently, testifying to the existence of an overwhelming sense of an anti-Semitic witch-hunt during the campaign. Even if some declared, for example that 'in [19]68, although I personally did not feel it, I did fall seriously ill because of this whole atmosphere of attacks against the Jews', ${ }^{55}$ such an experience of collective stigmatization must have affected not only those attacked with anti-Semitic slogans, but also the entire community. This was linked to feelings of exhaustion, tension, as well as helplessness, which emerge in the interviews:

Unlike the previous anti-Semitic waves, this one was official, by the party and the government, and that's why one suddenly felt helpless and vulnerable. I wasn't afraid that they would prepare camps for Jews - although people would talk constantly about this I didn't believe it - but mentally as a Jew I'd had enough of it all. ${ }^{56}$

A different attitude is revealed in experiences of direct threats, which were present especially among the parents of students active during the March protests and rallies. To some of them, they revived memories of

53 Stola, Kampania antysyjonistyczna, pp. 219-25.

${ }^{54}$ AD, fonds A-7, 'Interviews with emigrants from Poland from the 1969-1970 Aliyah', 15, fol. 4.

${ }^{55}$ AD, fonds A-7, 'Interviews with emigrants from Poland from the 1969-1970 Aliyah', 11, fol. 4.

${ }^{56} \mathrm{AD}$, fonds A-7, 'Interviews with emigrants from Poland from the 1969-1970 Aliyah', 5, fol. 8. 
the inter-war period, as was recalled by one of the émigrés: 'Only the incidents involving my son revealed the full hostility to me and the slogan "beat the Jew" lost nothing of its relevance. Anti-Semitism was common in school as well, and this was difficult to bear. ${ }^{57}$

The undeniable mood of hostility towards Jews gave rise to various other attitudes. What emerged as a consequence, as it were, of the presence of anti-Semitism was a sense of alienation; an awareness of growing barriers isolating the Jewish population from the rest of society. Such experiences were another aspect of the anti-Semitic campaign. Many of Sabina Lewin's interlocutors formulated the analysed problem aptly when responding to the question about the reasons behind their decision to leave Poland. The interviews feature simple sentences describing the migrants' perceptions: 'I didn't want to feel alienated again like in Poland' ${ }^{58}$ or 'I felt increasingly alienated in Poland'. ${ }^{59}$ Significantly, the first statement contains the word 'again', which probably refers to the inter-war period or the Holocaust. Others left not so much because a sense of actual alienation, but in its face or because they feared its inevitable coming: 'fearing isolation [...], which was revived anew. ${ }^{60}$

This sense of alienation is linked not only to exclusion and isolation, but also to loneliness. This last aspect is associated with another dimension of the campaign as a result of which Jewish families or families of Jewish origin left Poland. The variety of these contexts can be discerned in several interviews. One interviewee highlighted the problem of the common nature of emigration and diversity of age groups among the émigrés: 'Jews were leaving, we didn't want to be left alone. Only old people, pensioners, people unable to work stayed in Poland. ${ }^{61}$ Others cited primarily their social relations, citing as an important reason the 'mass emigration of Jews, among them my close friends.' ${ }^{62}$ There were also those who, despite similar experiences, needed more time to take a similar decision. This is illustrated by the example of one of the interviewees who admitted that:

${ }^{57}$ AD, fonds A-7, 'Interviews with emigrants from Poland from the 1969-1970 Aliyah', 7, fol. 5.

${ }^{58}$ AD, fonds A-7, 'Interviews with emigrants from Poland from the 1969-1970 Aliyah', 3, fol. 3.

${ }^{59}$ AD, fonds A-7, 'Interviews with emigrants from Poland from the 1969-1970 Aliyah', 7, fol. 5.

${ }^{60} \mathrm{AD}$, fonds A-7, 'Interviews with emigrants from Poland from the 1969-1970 Aliyah', 15, fol. 4.

${ }^{61}$ Ibid.

${ }^{62}$ AD, fonds A-7, 'Interviews with emigrants from Poland from the 1969-1970 Aliyah', 1, fol. 4. 
Despite March, despite visits to the railway station and goodbyes, I didn't want to leave Poland. The decision came half a year later. In September I was back in Warsaw and in the Dutch embassy I obtained visa promises, valid for a year, for the entire family. ${ }^{63}$

This process of becoming ready to leave was a multidimensional reality. There were undoubtedly many push factors after the end of the anti-Zionist witch-hunt and official end of the campaign. One of the most important among them, recurring in many interviews, was disappointment with communism. Bitterness at the system intensified especially in August 1968, when the Polish troops took part in the Warsaw Pact's intervention in Czechoslovakia. For some this was the final straw, the final argument tipping the complex profit and loss assessment, and it was after this event that they decided to leave Poland. One interviewee speaks of the role of the intervention in strengthening an earlier decision: 'The invasion of Czechoslovakia, which began after my family had submitted the emigration papers, consolidated my belief that I should leave this country, which was so horribly ideologically hypocritical. ${ }^{64}$ Another interviewee said this clearly in one sentence: 'The decision was made in [19]68, in August, after the Warsaw Pact troops entered Czechoslovakia. ${ }^{65}$ In the second half of the 1960s the events in Czechoslovakia and the slow internal transformation of the system taking place there generated not only interest among many people, especially in the neighbouring countries of the Eastern Bloc, but also expectations of similar actions in their homelands. In the view of many citizens of communist Poland, the intervention into events beyond their country's southern border was an act of aggression, sometimes compared to the 1967 events in the Middle East, as well as an embarrassment to the communist system, and put an end to hopes for greater liberalization and democratization in Poland. ${ }^{66}$ This is confirmed by a confession of one of the respondents:

For many years I lived in hope, still in hope. And then came [19]67, and even before the Six-Day War [Alexander] Dubček came to power

${ }^{63} \mathrm{AD}$, fonds A-7, 'Interviews with emigrants from Poland from the 1969-1970 Aliyah', 13, fol. 5.

${ }^{64} \mathrm{AD}$, fonds A-7, 'Interviews with emigrants from Poland from the 1969-1970 Aliyah', 4, fol. 6 .

${ }^{65}$ AD, fonds A-7, 'Interviews with emigrants from Poland from the 1969-1970 Aliyah', 13, fol. 5 .

${ }^{66}$ Łukasz Kamiński, ‘Reakcje społeczeństwa Dolnego Śląska na interwencję wojsk Układu Warszawskiego w Czechosłowacji', in Opozycja i Opór Społeczny w Polsce po 1956 roku, vol. 1, ed. Tomasz Kozłowski and Jan Olaszek, Warsaw, 2011, pp. 193-217 (p. 202). 
in Czechoslovakia. This change revived my hopes again; then there was the war in Israel and the mad witch-hunt for Jews on the part of the government and the party, I became pessimistic and simply didn't know what to do. What mainly determined my emigration out of Poland, not to Israel but out of Poland, was a short radio announcement that Dubček had ceased to be the general secretary and had been replaced with Husák. That was the final straw. I knew this was the end, that there was nothing for me to do here. ${ }^{67}$

Such statements reveal the ideological side of some interviewees, who may have been previously strongly attached to communism. This view of the reality from the perspective of ideology contained a unique desire to repair or transform the system, and a belief in Poland's regime. The discussion about the events in Czechoslovakia was for some more painful than the earlier events of the anti-Zionist campaign. The attack on one of the party activists of Jewish origin was an experience revealing the painful reality to him:

In the last few months before emigrating I did not hide my stance on Czechoslovakia, I expressed it at a party meeting. After that I began to be harassed, people started scheming against me by accusing me of having different views on the invasion of Czechoslovakia. [...] Another comrade accused me of an anti-party attitude toward the matter of Czechoslovakia - in other words, there began a vulgar provocation against me personally. ${ }^{68}$

The two threads of disappointments in the accounts cited above - one relating to the invasion of Czechoslovakia and one, more broadly, to the entire system ${ }^{69}$ - seem to be a characteristic feature of this generational group. The latter aspect appears in many subsequent accounts. ${ }^{70}$ There are references to the interviewees' party activism, their contribution to

${ }^{67} \mathrm{AD}$, fonds A-7, 'Interviews from emigrants from Poland from the 1969-1970 Aliyah', 12, fol. 7.

${ }^{68} \mathrm{AD}$, fonds A-7, 'Interviews with emigrants from Poland from the 1969-1970 Aliyah', 18, fol. 6.

${ }^{69} \mathrm{AD}$, fonds A-7, 'Interviews with emigrants from Poland from the 1969-1970 Aliyah', 16, fol. 5-6.

${ }^{70}$ It is worth noting, after Jerzy Eisler and Marcin Zaremba, that it was precisely after March 1968 that there occurred 'the final collapse of Marxist ideology in the Polish United Workers' Party', a fact suggested, according to historians, by the category of 'nationality' added to the personal details form for party activists and placed higher than the 'class background', see Jerzy Eisler, 'Rok 1968: Żydzi, antysemityzm, emigracja’, in Z przeszłości Żydów polskich: Polityka, gospodarka, kultura, społeczeństwo, ed. Jacek Wijaczka and Grzegorz Miernik, Cracow, 2005, pp. 327-58 (p. 357). 
the rebuilding of Poland after the war, and honest confessions of faith in the system:

The only link between myself and Poland was ideology. I would certainly have left Poland immediately if I had known what form socialism would take. [...] By as early as [19]57 I had already decided to leave, but stayed because of family complications. I could not predict what would happen in [19]67-[19]68, but I knew that there was no place for me in Poland. I no longer had anything to do with this country and this nation. I witnessed the abuses of communism, I witnessed anti-Semitism. I was the secretary of the local party organization in my district. After [19]57 and the elections to the local organization, I refused to accept the position of secretary. The reasons were political; I couldn't support the party's position in situations and causes which I believed were not just. I didn't leave the party in protest, but I no longer wanted to be active in it. I handed in my party membership card before submitting my emigration papers. I added a declaration that I was handing in my membership card because of my emigration to Israel. ${ }^{71}$

A characteristic element, present in other statements, is a comparison between March 1968 and the events that happened a decade earlier. The anti-Semitism present in 1956 and 1957, during the 'Thaw' and attempts to critically assess the Stalinism period, was different in nature, a fact discussed in detail by both the émigrés and scholars. ${ }^{72}$ The possibility of leaving Poland in those days - taken advantage of by 50,000 people - was for some an opportunity to leave a closed country, to implement a decision, taken much earlier, to emigrate. ${ }^{73}$ This experience influenced the Jewish community in Poland - not only its size but also its attitude toward the country. Those who remained were those who did not see a future for themselves in Israel and consciously decided to live in Poland. This may have been influenced by the revival of the American Jewish Joint Distribution Committee (Joint) in Poland and the initial liberalization of social life after the 'Thaw'. They felt attached to Poland, not only through ideology, but also to a broadly-defined culture. It was only the 1968 campaign that

${ }^{71} \mathrm{AD}$, fonds A-7, 'Interviews with emigrants from Poland from the 1969-1970 Aliyah', 19, fol. 7.

72 They mean here primarily the tone of the campaign and its scale, as well as the fact that it was initiated mainly by the government. When discussing the events of 1956, Paweł Machcewicz also describes the significance of political party games or socio-political anti-Semitism, though appearing in a different context and on a different scale; see Paweł Machcewicz, 'Antisemitism in Poland in 1956', Polin, 9, 1996, pp. 170-86 (pp.182-83). For more on anti-Semitism in 1956, see for example Ewa Węgrzyn, Wyjeżdżamy! Wyjeżdżamy?! Alija gomułkowska 1956-1960, Budapest and Cracow, 2016, pp. 79-87.

${ }^{73}$ E. Węgrzyn gives the number of approximately 50,000 emigrants, cf. ibid., p. 320. 
led to their complete loss of faith in the system and in their ability to function normally in their homeland:

The anti-Semitic campaign was known to us also in [19]57. At that time I was against leaving, hoping that this was a passing phenomenon, that it would not be repeated, and that we should try to live on because we had contributed too much to People's Poland to give up on it just like that. [...] The most horrible thing was that the whole campaign in 1968 came from the top, from the party and the government, while in [19]57 it was a grassroots movement. ${ }^{74}$

Finally, it is worth paying attention to personal factors, stemming from the respondents' life situations. For some parents it was the decision of their sons and daughters that was binding - or at least very important in their own decision to leave the country. Such a situation is described by one of the respondents as follows:

The decision to emigrate came from our daughter. We lived in a beautiful, comfortable flat, we had many privileges, earned a lot and had a high-quality life. But during the student unrest, when her friends, Poles, forbade her - with the best intentions - to take part in a rally in order for the communist police not to treat the rally as yet another Jewish provocation, my daughter came back home broken-hearted and after a sleepless night told us she had decided to leave Poland. If I'm different - she said - there is no place for me in this country. ${ }^{75}$

In this fragment the turning point is a meeting of a young girl of Jewish origin with her peers, a meeting that made her aware of her otherness and the different nature of her life story. Another interviewee found herself in a similar situation. She too decided to leave because of her loved ones:

I left Poland with a heavy heart, as a result of pressure from my family. The witch-hunt against Jews organized by the party and the government disgraced them, not me. [...] I was afraid of emigration. My Polish friends would visit me even at the worst of times, because they were ashamed of all this. But after one visit there came a breakthrough and I decided to emigrate. I noticed that my contacts with my Polish friends were beginning to be accompanied by a completely new, hitherto unknown humiliating feeling, and I thought that this humiliating gratitude would always

${ }^{74} \mathrm{AD}$, fonds A-7, 'Interviews from emigrants from Poland from the 1969-1970 Aliyah', 16, fol. 5.

${ }^{75} \mathrm{AD}$, fonds A-7, 'Interviews with emigrants from Poland from the 1969-1970 Aliyah', 8, fol. 7. 
accompany me, that I would have to feel grateful to my bosses for not having fired me, to the caretaker who still kept saying good morning to me etc. After realizing this, I understood that there was no place for me in Poland any more, that I was forced to emigrate for better, or rather, for worse. I was numb with pain and despair, but also firm in my decision. ${ }^{76}$

Personal relations, the experience of humiliation, a new quality in contacts with friends, were in this case elements changing the perception of reality and contributing to the decision to emigrate. If we add to this the influence of the family, the loved ones wanting to emigrate, we see even more clearly the significance of human relations - both individual contacts as well as one's milieu - and their impact on emigration.

The anti-Zionist campaign was directed against Jews and people of Jewish origin. In defining this last phrase, we need to note that those who were attacked included both people who admitted to their lineage and identified themselves with Jewishness or Jewish culture as broadly defined; as well as people who had decided to become assimilated, to become Poles or reject or not mention their Jewish roots. The events of March brought much disappointment in this respect. As one émigré recalled, the reasons for departure also included the fact that 'the concept of assimilation into Polishness collapsed completely. ${ }^{77}$ Being publicly fingered for being of Jewish origin or stigmatized as a 'Jew' was for many people one of the biggest shocks of that period. This was especially true of some young people, teenagers brought up in Polish culture, who listened in disbelief to information about the origin of their families. A completely different situation concerned those individuals who functioned in Jewish milieus, cultivating their Jewish identity. The campaign, which was an explosion of nationalistic moods, made many such people realize they needed to leave the country. One interviewee declared: 'I regarded myself as a Jew, I never felt I was a Pole. I believe that a Jew's place is in Israel. ${ }^{78}$ Another one presented the arguments for emigration in the same spirit: 'I understood that as a Jew I could not stay in this country, that there was no place for me here. As a Jew with

${ }^{76} \mathrm{AD}$, fonds A-7, 'Interviews with emigrants from Poland from the 1969-1970 Aliyah', 17, fol. 2.

${ }^{77}$ AD, fonds A-7, 'Interviews with emigrants from Poland from the 1969-1970 Aliyah', 10, fol. 6.

${ }^{78} \mathrm{AD}$, fonds A-7, 'Interviews with emigrants from Poland from the 1969-1970 Aliyah', 3, fol. 6. 
a sense of national belonging, I couldn't come to terms with all this and that's why I decided to leave only for Israel. ${ }^{19}$

An even more dramatic picture was painted by a later interviewee: 'I became sick and tired of being in a place where one is looked upon differently for being a Jew and is another candidate for being kicked out only because of his Jewish origin. ${ }^{180}$ Such statements were a response to anti-Semitic slogans, a declaration of identity, and a clear choice of emigration destination. A separate issue is the extent to which the anti-Zionist campaign generated or consolidated such attitudes among Jews and contributed to the already-mentioned evolution of identity. In the face of stigmatization and alienation, a sense of belonging to a group may have become increasingly important and relations with other Jews stronger and more durable.

\section{Conclusions}

In the analysed reminiscences the reasons for leaving Poland are both multidimensional as well as strongly interlinked. This is evidenced by the diversity of arguments given as well as by the attitude of the interviewees, who in many cases listed several equally important motives. All are part of one set, which has different common elements in the case of different respondents. For some disappointment with communism and the departure of friends were more important, while others highlighted the experience of anti-Semitism, family pressure, or a sense of alienation. There are many more similar combinations of various reasons, especially given that the personal accounts will always be different (because of different levels of political involvement, different work environments, places of residence and so on).

A very clear element recurring in the analysed fragments is disappointment with communism and, as a consequence, with the Polish United Workers' Party. As we see in the respondents' accounts, this attitude did not appear overnight in March 1968, but was a long process, an important element of which was the period of 1956-57. At that time, despite doubts and a wave of migrations, the respondents decided to stay in Poland. Over ten years later they decided not so much to go to Israel, but above all to leave Poland. The event that influenced

${ }^{79} \mathrm{AD}$, fonds A-7, 'Interviews with emigrants from Poland from the 1969-1970 Aliyah', 6, fol. 7.

${ }^{80} \mathrm{AD}$, fonds A-7, 'Interviews with emigrants from Poland from the 1969-1970 Aliyah', 8, fol. 7. 
that decision in several cases was the intervention of the Warsaw Pact troops in Czechoslovakia. It could be said that it was a catalyst that launched an immediate reaction. Although it does appear in other studies, its importance may not be stressed enough, especially when we speak about people who until a certain point had sympathized with the government or had been active at various party levels.

Another element present in the interviews is subjective images, often filled with emotions, dilemmas, and difficult experiences. Each decision to emigrate must have been accompanied by reflections on the years spent in Poland, the relations between people, and on career(s) and many other aspects of everyday life. Each account constitutes an individual perspective, eventually coming down to the same conclusion concerning emigration. Sometimes - and this point is worthy of stressing again - it was a decision spread out over time and determined by many factors.

Undoubtedly, a common denominator for all interviewees was the events of spring 1968, events to which it was hard, if not impossible, to remain indifferent. Anti-Semitism, a sense of alienation, helplessness, hostility towards Jews, departures of friends, pressure from the family, children, disappointment with communism, events in Czechoslovakia - these were some of the experiences of a broadly-defined 'anti-Zionist campaign', in this context being synonymous with many reasons behind leaving Poland.

Archive of the Diaspora, Tel Aviv, fonds A-7, 'Interviews with emigrants from Poland from the 1969-1970 Aliyah', research questionnaire

1. First and last name.

2. Place of birth.

3. Age (optional).

4. Education (primary, secondary, state, private, Polish, Jewish school, school run by soc.-pol. organization).

5. Profession by training.

6. Current occupation.

7. Place of residence during the war 1939-1945.

8. What did the respondent do during the war; did the respondent serve in the army and if so, which army and where.

9. When did the respondent return to Poland, from where, and in what capacity - as a repatriate, serviceman/woman, released from labour camp. 
10. Place and type of work in Poland; positions.

11. Community and political activism:
a) before the war
b) during the war
c) after the war.

12. Relations at work, with party organizations and trade unions, with superiors, subordinates, colleagues - had there been conflicts, their causes, relations stemming from the respondent's attitude.

13. Relations with neighbours, causes of conflicts if applicable, good, friendly/

14. Respondent's attitude to his/her milieu, did the respondent mention his/her Jewishness.

15. Attitude to Poles, local party and administrative apparatus, at the work place, to Jewish causes, to Israel, to Jewish personnel in the party and administrative apparatus.

16. Contacts with Jews and Jewish culture, did the respondent take part in the the cultural and social life of Jews in Poland (theatre, work, summer camps for children).

17. What does the respondent know about assistance provided by Jewish organizations from the West to Polish Jews. Attitude of the Polish authorities to these organizations and their assistance.

Attitude to Israel, did the respondent have relatives, did he/she correspond, visit.

18. Reasons for leaving Poland.

19. Date of arrival in Israel.

20. Why did the respondent choose Israel as his/her emigration destination.

(Translated by Anna Kijak)

(Proofreading by James Hartzell)

\section{Summary}

As a consequence of the events of March and the anti-Semitic campaign of 1968, a significant part of Poland's Jewish population and many individuals of Jewish origin left the country. This group, referred to in the literature as 'post-March émigrés', settled in various countries, including Denmark, Sweden, the USA and Israel. This article focuses on emigration to that latter country, drawing on accounts compiled shortly after settlement, that is in the 1970s, of migrants from the generation of Holocaust survivors. The main objective of the article is to establish, describe, and analyse the reasons presented by the interviewees for leaving Poland 
and choosing Israel as their final destination. These elements include various events and phenomena seen by the interviewees as factors driving them out of the country: for example the anti-Semitic witch-hunt; a sense of alienation; social relations; as well as disappointment with the communist system and the events in Czechoslovakia at the time. The whole set of factors makes up a multifaceted mosaic and provides a deeper insight into the behaviours and motivations of this group of people in the period immediately following 1968.

(Translated by Anna Kijak)

(Proofreading by James Hartzell)

\section{Bibliography}

Berendt, Grzegorz, 'Emigracja ludności żydowskiej z Polski w latach 1945-1967', Polska 1944/45-1989: Studia i Materiały, 7, 2006, pp. 25-60.

Chylińska, Kamila, 'Emigracja polska po 1967 r.', Kultura, 1970, 11/278, pp. 17-55.

Dąbrowska, Kamila, 'Od autobiografii do historii - konstruowanie pamięci indywidualnej i zbiorowej Żydów mieszkających na Dolnym Śląsku po II wojnie światowej', doctoral dissertation, Faculty of History, University of Warsaw, 2011.

Dzieje Uniwersytetu Warszawskiego 1915-1945, ed. Piotr M. Majewski, Warsaw: Wydawnictwa Uniwersytetu Warszawskiego, 2016.

Eisler, Jerzy, Marzec 1968: Geneza, przebieg, konsekwencje, Warsaw: Państwowe Wydawnictwo Naukowe, 1991.

Eisler, Jerzy, Polski rok 1968, Warsaw: Instytut Pamięci Narodowej, 2006.

Eisler, Jerzy, 'Rok 1968: Żydzi, antysemityzm, emigracja', in Z przeszłości Żydów polskich: Polityka, gospodarka, kultura, spoteczeństwo, ed. Jacek Wijaczka and Grzegorz Miernik, Cracow: Wydawnictwo Towarzystwa Naukowego 'Societas Vistulana', 2005, pp. 327-58.

Górniok, Łukasz, Swedish Refugee Policymaking in Transition?: Czechoslovaks and Polish Jews in Sweden, 1968-1972, Umeå: Department of Historical, Philosophical and Religious Studies, Umeå University, 2016.

Grabski, August, 'Żydzi a polskie życie polityczne (1944-1949)', in Nastęstwa zagłady Żydów: Polska 1944-2010, ed. Feliks Tych and Monika Adamczyk-Garbowska, Lublin : Wydawnictwo Uniwersytetu Marii Curie-Skłodowskiej; Żydowski Instytut Historyczny im. Emanuela Ringelbluma, 2011, pp. 157-88.

Grynberg, Mikołaj, Księga wyjścia, afterword Piotr Osęka, Wołowiec: Wydawnictwo Czarne, 2018.

Ilicki, Julian, Den föränderliga identiteten: Om identitetsförändringar hos den yngre generationen polska judar som invandrade till Sverige under åren 1968-1972 [The Changeable Identity: On Changing Identity among the Younger Generation of Polish Jews Immigrating to Sweden in 1968-1972], Åbo: Sällskapet för judaistisk forskning, 1988. 
Isański, Jakub, Migracje i transfery kapitału społecznego, Poznań: Wydawnictwo Naukowe UAM, 2015.

Jaskułowski, Krzysztof, and Marek Pawlak, 'Główne teorie migracji międzynarodowych: Przegląd, krytyka, perspektywy', Sprawy Narodowościowe. Seria nowa, 48, 2016, pp. 128-46.

Jaźwińska, Ewa, Wojciech Łukowski and Marek Okólski, Przyczyny i konsekwencje emigracji z Polski, Warsaw: Instytut Studiów Społecznych Uniwersytetu Warszawskiego, 1997, Prace Migracyjne, vol. 7.

Kaczmarczyk, Paweł, Migracje zarobkowe Polaków w dobie przemian, Warsaw: Wydawnictwa Uniwersytetu Warszawskiego, 2005.

Kamiński, Łukasz, 'Reakcje społeczeństwa Dolnego Śląska na interwencję wojsk Układu Warszawskiego w Czechosłowacji', in Opozycja i Opór Społeczny w Polsce po 1956 roku, ed. Tomasz Kozłowski and Jan Olaszek, Warsaw: Instytut Pamięci Narodowej, 2011, pp. 193-217.

Kaźmierska, Kaja, and Katarzyna Waniek, Autobiograficzny wywiad narracyjny: Metoda - technika - analiza, Łódź: Wydawnictwo Uniwersytetu Łódzkiego, 2020.

Kijek, Kamil, Dzieci modernizmu: Świadomość, kultura i socjalizacja polityczna młodzieży żydowskiej w II Rzeczypospolitej, Wrocław: Wydawnictwo Uniwersytetu Wrocławskiego, 2017.

Kossewska, Elżbieta, Ona jeszcze mówi po polsku, ale śmieje się po hebrajsku: Partyjna prasa polskojęzyczna a integracja kulturowa polskich Żydów w Izraelu (1948-1970), Warsaw: Wydawnictwa Uniwersytetu Warszawskiego, 2015.

Krajobraz po szoku, ed. Anna Mieszczanek, Warsaw: Przedświt, 1989.

Kurkowska-Budzan, Marta, 'Informator, świadek historii, narrator - kilka wątków epistemologicznych i etycznych oral history', Wrocławski Rocznik Historii Mówionej, 1, 2011, pp. 9-34.

Lewin, Sabina, Materiały pomocnicze do historii szkolnictwa i oświaty: dla studentów Studium dla Pracujacych Wydz. Pedagogiki U.W. Cz. 1: Wychowanie w ustroju niewolniczym i feudalnym, Warsaw: Uniwersytet Warszawski. Dział Wydawnictw, 1958.

Lewin, Sabina, Podstawy wychowania przedszkolnego w Polsce Ludowej, Warsaw: Państwowe Zakłady Wydawnictw Szkolnych, 1969.

Lewin, Sabina, U poczatków polskiej teorii wychowania dziecka $w$ wieku przedszkolnym, Warsaw: Nasza Księgarnia, 1960.

Lewin, Sabina, Żydowska młodzież w strajku szkolnym 1905 r., Warsaw: Żydowski Instytut Historyczny, 1996.

Machcewicz, Paweł, 'Antisemitism in Poland in 1956', Polin, 9, 1996, pp. 170-86.

Marzec 1968: Trzydzieści lat później: Materiały z konferencji zorganizowanej pod patronatem prezydenta m. stot. Warszawy przez Instytut Historyczny UW, Instytut Studiów Politycznych PAN oraz Żydowski Instytut Historyczny przy wspótpracy Wydawnictwa Naukowego PWN SA na Uniwersytecie Warszawskim 6 i 7 marca 1998 r., 2 vols, Warsaw: Wydawnictwo Naukowe PWN, 1998, vol. 1: Referaty, ed. Marcin Kula, Marcin Zaremba and Piotr Osęka. 
Nowak, Marek, 'Polska migracja: Motywy mobilności, jej dynamika i propozycja socjologicznej rekonceptualizacji', Ruch Prawniczy, Ekonomiczny i Socjologiczny, 76, 2014, 3, pp. 281-99.

Nalewajko-Kulikov, Joanna, Obywatel Jidyszlandu: Rzecz o żydowskich komunistach $w$ Polsce, Warsaw: Wydawnictwo Neriton; Instytut Historii PAN, 2009.

Naszkowska, Krystyna, Ani tu ani tam: Marzec '68 - powroty, Warsaw: Wielka Litera, 2018.

Naszkowska, Krystyna, and Joanna Helander, Wygnani do raju: Szwedzki azyl, Warsaw: Wydawnictwo Agora, 2017.

Osęka, Piotr, Marzec '68, Cracow: Wydawnictwo Znak; Instytut Studiów Politycznych Polskiej Akademii Nauk, 2008.

Osęka, Piotr, My, ludzie z Marca: Autoportret pokolenia '68, Warsaw: Instytut Studiów Politycznych Polskiej Akademii Nauk; Wołowiec: Wydawnictwo Czarne, 2015. Osęka, Piotr, Syjoniści, inspiratorzy, wichrzyciele: Obraz wroga w propagandzie marca 1968, Warsaw: Żydowski Instytut Historyczny, 1999.

Polonsky, Antony, Dzieje Żydów w Polsce i Rosji, Warsaw: Wydawnictwo Naukowe PWN, 2014.

Ruchniewicz, Małgorzata, Repatriacja ludności polskiej z ZSRR w latach 1955-59, Warsaw: Oficyna Wydawnicza Volumen, 2000.

Ruta, Magdalena, Bez Żydów?: Literatura jidysz w PRL o Zagładzie, Polsce i komunizmie, Cracow and Budapest: Wydawnictwo Austeria, 2012.

Rykała, Andrzej, “"Produktywizacja” Żydów w Polsce po drugiej wojnie światowej na przykładzie działalności rolniczej’, Prace i Studia Geograficzne, 61, 2016, 61, 1, pp.151-63.

Rykała, Andrzej, Przemiany sytuacji społeczno-politycznej mniejszości żydowskiej $w$ Polsce po drugiej wojnie światowej, Łódź: Wydawnictwo Uniwersytetu Łódzkiego, 2007.

Schatz, Jaff, The Generation: The Rise and Fall of the Generation of Jewish Communists of Poland, Lund: Lund University Department of Sociology, 1989.

Schatz, Jaff, 'Świat mentalności i świadomość komunistów polsko-żydowskich szkic do portretu', in Społeczność żydowska w PRL przed kampania antysemicka lat 1967-1968 i po niej, ed. Grzegorz Berendt, Warsaw: Instytut Pamięci Narodowej, 2009, pp. 43-55.

Shore, Marci, Caviar and Ashes: A Warsaw Generation's Life and Death in Marxism, 1918-1968, New Heaven, CT, and London: Yale University Press, 2006.

Słownik socjologii i nauk społecznych, ed. Gordon Marshall and Marek Tabin, Warsaw: Wydawnictwo Naukowe PWN, 2004.

Sobel, Leopold, "'Budujemy nowy dom": Polska i emigracja marcowa w materiałach opublikowanych w "Plotkies"', in Społeczność żydowska w PRL przed kampania antysemicka lat 1967-1968 i po niej, ed. Grzegorz Berendt, Warsaw: Instytut Pamięci Narodowej, 2009, pp. 218-27.

Starnawski, Marcin, 'Pokolenie Marca '68 na wygnaniu: Wzory integracji i zmiany identyfikacyjne', Kwartalnik Historii Żydów, 2019, 2, pp. 389-416. 
Starnawski, Marcin, Socjalizacja i tożsamość żydowska w Polsce powojennej: Narracje emigrantów z pokolenia marca '68, Wrocław: Wydawnictwo Naukowe Dolnośląskiej Szkoły Wyższej, 2016.

Stola, Dariusz, 'Anti-Zionism as a Multipurpose Policy Instrument: The Anti-Zionist Campaign in Poland, 1967-1968', Journal of Israeli History, 25, 2006, 25, 1, pp. 175-201.

Stola, Dariusz, Emigracja pomarcowa, Warsaw: Instytut Studiów Społecznych Uniwersytetu Warszawskiego, 2000.

Stola, Dariusz, 'Jewish Emigration from Communist Poland: The Decline of Polish Jewry in the Aftermath of the Holocaust', East European Jewish Affairs, 47, 2017, 2-3, pp. 169-88.

Stola, Dariusz, Kampania antysyjonistyczna w Polsce 1967-1968, Warsaw: Instytut Studiów Politycznych Polskiej Akademii Nauk, 2000.

Stola, Dariusz, Kraj bez wyjścia? Migracje z Polski 1949-1989, Warsaw: Instytut Pamięci Narodowej, 2010.

Stolarz, Agata, 'Dzielenie się pamięcią': Praktyka i teoria historii mówionej, Lublin: Instytut Europy Środkowo-Wschodniej, 2016.

Szajda, Marek, ‘Epilog “Historii złudzeń”: Obraz Polski w latach 1944-1968 we wspomnieniach Klemensa Nussbauma', Sobótka, 74, 2019, 3, pp. 137-63.

Szaynok, Bożena, 'Raport o stanie badań na temat emigracji z Polski Żydów obywateli polskich po II wojnie światowej (1944-1989)', in Polska emigracja polityczna 1939-1990: Stan badań, ed. Sławomir Łukasiewicz, Warsaw: Instytut Pamięci Narodowej, 2016, pp. 395-425.

Szumiło, Mirosław, ‘Żydzi w kadrze kierowniczej Związku Patriotów Polskich w ZSRS (1943-1946)', in Elity i przedstawiciele społeczności żydowskiej podczas II wojny światowej, ed. Aleksandra Namysło and Martyna Grądzka-Rejak, Cracow, Katowice and Warsaw: Instytut Pamięci Narodowej, 2017, pp. 337-50.

Torańska, Teresa, Jesteśmy: Rozstania '68, Warsaw: Świat Książki, 2008.

Tuszyńska, Agata, et al., Bagaż osobisty: Po Marcu, Warsaw: Dom Spotkań z Historią, 2018.

Węgrzyn, Ewa, Wyjeżdżamy! Wyjeżdżamy?! Alija gomułkowska 1956-1960, Budapest and Cracow: Wydawnictwo Austeria, 2016.

Wiszniewicz, Joanna, Życie przecięte: Opowieści pokolenia Marca, Wołowiec: Wydawnictwo Czarne, 2008.

Biography: Marek Szajda - graduate in History and Ethnology from the Department of Interdisciplinary Studies in the Humanities and Social Sciences, University of Wrocław and the Centre for Jewish Culture and Languages, University of Wrocław. He has also studied in Cracow, Tel Aviv and Jerusalem. Doctoral student at the Institute of History, University of Wrocław and senior specialist in the Research Department of the Centre for 'Remembrance and Future'. He is interested in Jewish history and culture, contemporary Polish history, history of Silesia, regional studies and oral history. He is secretary of the editorial committee of Wrocławski Rocznik Historii Mówionej (Wrocław Yearbook of Oral History). 